\title{
An Evaluation of a Key Innovation: Mobile Learning
}

\author{
Dr. Belle Louis Jinot
}

\author{
Lecturer (Education) \\ Open University of Mauritius \\ Reduit
}

\section{Doi: 10.2478/ajis-2019-0014}

\begin{abstract}
This paper examines the impact of m-learning as an innovative tool that is still in its infancy in many countries, but that can significantly contribute to effective teaching and learning in the context of the digital age. Based on the theoretical principles of learning, the uses of $m$-learning are reviewed. To provide complete insights into its potential adoption in higher education institutions in countries such as Mauritius and Nigeria, the various emerging issues such as technical issues, usability issues, content security and copyright issues as well as issues relating to privacy and cyber bullying are discussed. The paper suggests some of the future trends in the adoption of m-learning, but it concluded that it may not be successful due to other challenges that are typical to many countries in Africa. African countries are faced with context-bound and technological constraints that are hindering the leaners of higher education institutions to benefit from the learning advantages that they may get to improve their learning and for the countries to give more access to higher education through the use of open education that may be technologically enhanced.
\end{abstract}

Keywords: m-learning, innovation, uses, emerging issues

\section{Introduction}

Mobile learning (M-learning) was originally defined as any electronic learning that occurs through mobile computational devices, be it Palms, Windows CE machines or a digital cell phone (Quinn, 2000). With the increased use of mobile devices like iPad, smartphones, tablets and Personal Digital Assistants (PDAs) (Goggin, 2006) by the 'new millennium learners' doing multitasks, preferring multimedia to written texts, collaborating and doing networking, opting for games than for serious tasks, and being more comfortable with a "customised, collaborative and interactive learning" (Bidin and Ziden, 2013), there has been an evolution in the delivery of knowledge through digital learning from d-learning to e-learning and finally to M-learning model. M-learning has now gained the characteristics such as mobility, access, immediacy, situativity, ubiquity, convenience and contextuality (Pedro, Barbosa \& Santos, 2018). In the context of higher education, M-learning implies the mobility of learners, the mobility of technology and the mobility of learning (Al-Adwan, Al-Madadha \& Zvirzdinaite, 2018) that occur anywhere and anytime (Traxler, 2007; Wang, Wu \& Wang, 2009; Shih et al., 2011). So, it is not only about technology (Unwin, 2015), but it is also an innovative teaching and learning approach that uses mobile devices to extend traditional instruction and promote sustainable student engagement with greater connectivity with other persons and resources across multiple contexts (Rikala, 2016). Parsons (2014) added that the learning may be on the move or static, in formal or informal settings, working collaboratively or alone; for example, field trips, museum visits.

Though Thomas, Singh and Gaffar (2013) consider M-learning as an emerging trend that is 
still in its infancy, yet it has much contributed to making teaching and learning more attractive and promising (Kukulska-Hulme, 2009; Biden \& Ziden, 2013; Mehdipour \& Zerehkafi, 2013). M-learning promotes self-regulated learning whereby learners are at the centre of the learning process: they may decide on their learning through its evaluation stage (Biden \& Ziden, 2013) as they have their voice and choice in learning. It supports for them to be self-organised (Kramer, 2005), through collaborative learning, exploratory (enquiry-oriented) learning outside the classroom and gamebased learning, as they may develop communication, creativity, problem-solving and higher order skills (Sung, Chang \& Lui, 2016). These are innovative teaching and learning methods. Besides, Mlearning integrates content and process through learning activities that are context-bound, allowing the possibility for scaffolding (Martin \& Ertzberger, 2013). Through this situated and ubiquitous learning, learners are able to enrich their experience by co-creating their knowledge, through notestaking and pictures, observation, comparing knowledge in situation with online knowledge, sharing the information, formulating responses to questions that emerge as learning takes place, giving and receiving immediate feedback from other learners and the teacher, and greater social interactions (Alrusheedi, Capretz \& Raza, 2015; Foti \& Mendez, 2014; Al Hassan, 2015; Brown \& Mbati, 2015). Moreover, it caters for different learning styles of learners as mobile devices have different applications (Al Hassan, 2015) and learners can learn according to their abilities, needs and aptitudes (Batista \& Barcelos, 2014).

Furthermore, with the rapid progress and diffusion of technology in remote places in Africa and Asia, M-learning contributes to lifelong learning by giving access to education (Education for All Goal 3) (Unwin, 2015; GSMA, 2013). M-learning initiatives are MoMath in South Africa and BridgelT in Tanzania (Brown \& Mbati, 2015). They bring new learning opportunities to those learners who might not have equitable access to college education (Wishart \& Green, 2010). It helps, therefore, in improving levels of literacy, numeracy and participation in education among young adults (Parajuli, 2016).

\section{M-learning: An Innovative Pedagogy}

M-learning is innovative as learning content is delivered through mobile devices such as notebooks, mobile tablets, iPods touch and iPads with internet connectivity which gives greater possibility for interaction and collaboration among learners and between learners and teachers (Parajuli, 2016). Besides, with the learner-generated contents integrated with social media, the use of mobile gamebased learning (gamification) and augmented reality, learners may connect, communicate, collaborate and create new enriching learning experiences through situational instructional activities (Huizenga et al., 2009; Urwin, 2015; Mehdipour \& Zarehkafi, 2013). This can make learning flexible in terms of location and time (Elmorshidy, 2012). Moreover, mobile phone applications such as Blackboard may be used by learners to access course content for grade viewing, viewing and posting discussion threads, downloading pdfs shared by the teacher and uploading of assignments (Foti \& Mendez, 2014). With M-learning, learners may also use applications to create flashcards and to access and edit working documents on Google Docs for assignments (Miller, 2012).

M-learning uses quizzes for formative and summative assessment. An example was the Efike mobile social quiz platform used by Nigerian learners (Unwin, 2015). Besides, the methods of assessment have changed to make learning and assessment more enjoyable and appropriate to learners. E-portfolios, such as online multimedia records of achievement, that focus on the process of learning, as captured by the mobile phone, are used (Wishart \& Green, 2010). For instance, PDAs mobile cameras are used to record the process of design, development and creation for later assessments in subjects such as Design and Technology and Arts (Kimbell et al., 2007).

In fact, the project of using PDAs, initiated by the European-led MOBILearn (2002-2006), to record information and experiences outside the classroom was innovative: it supported teaching and learning within the classroom environment (Urwin, 2015). The My ArtSpace project was used by school learners on a trip to visit a museum; they used their mobile phones to access multimedia content that was linked to specific exhibits and used this facility to send audio recordings, notes and photos captured at the museum to a website. That website allowed them to share and discuss their acquired knowledge when they are back to the classroom (Sharples et al., 2007). 


\section{Theoretical Background}

Mobile learning as an innovation is based on various perspectives of theorists. Some of them are discussed in this section: behaviourism, cognitivism, socio-constructivism, heutagogy, rhizomatic learning, connectivism, navigationism and lifelong learning.

\subsection{Behaviourism}

According to behaviourism, learning is said to have occurred when the learner has the evidence about the appropriate reinforcement about an association between a specific response and stimulus (Smith \& Ragan, 2005). Based on this, M-learning focuses on information and content delivery such as drill and feedback, language learning, quizzes and practices; for instance, it uses applications as such SMS, MMS, video recorder softwares and mobile response systems (Keskin \& Metcalf, 2011).

\subsection{Cognitivism}

Learning occurs when the individual acquires or reorganises his/her cognitive structures through which he/she processes and stores information (Good and Brophy, 1990). M-learning is used to deliver content and information through images, audio, video, texts, animation, and podcasting (Keskin \& Metcalf, 2011).

\subsection{Social constructivism}

Learning occurs when a learner reaches his/her "zone of proximal development" (Vygotsky, 1978), that is through collaboration and sharing of the knowledge acquired with other learners. As such learning is an activity process (Bruner, 1966). Additionally, situated learning theory explains the characteristics of social participation (Brown et al., 1989), whereby mobile learning provides the opportunities for learners to actively participate or interact in knowledge co-construction. Simulation, interactive podcasting and multimedia museums are examples of how M-learning is based on socio-constructivism. This has given rise to the term "class-sourcing" whereby learners choose, analyse, organise and communicate the information through multimedia (Tsipurksy, 2013). It is evident that the M-learning was based on the acquisition-participation metaphor of Sfard (1998).

\subsection{Heutagogy}

Mobile learning is also based on heutagogy, which focuses on the learner as the creator of new knowledge, not the teacher, in an interconnected world. The learner shares knowledge and resources in a self-determined way (Ashton \& Newman, 2006) and he/she grows emotionally from this experience (Brown \& Mbati, 2015). Indeed, M-learning allows learners to be connected to others and creating knowledge at the same time.

\subsection{Rhizomatic learning}

The six principles underlying this model of learning are connectivism, multiplicity, cartography, heterogeneity, A-signifying rupture and decalcomania (Deleuze \& Guatarri, 2013). It assumes that there is no cutting-edge knowledge in a world where knowledge is constructed and negotiated between learners, with no beginning and no end (Cormier, 2011). With M-learning, learners are constantly creating knowledge depending on the context and learning experiences. This is done through blogging, for instance.

\subsection{Connectivism}

The principles of connectivism are, inter alia, learning and knowledge rest in diversity of knowledge; 
knowledge is the process of connecting nodes or information sources; learning may reside in nonhuman appliances; and connections facilitate continual learning (Siemens, 2005). So, connectivism allows learners to delearn, relearn and learn what knowledge they actually have by exploring the ideas of others in the learning network. M-learning gives learners access to a diversity of information sources and opportunities of knowledge creation through applications such as social networks, discussion platforms, mobile forums and podcasting.

\subsection{Navigationism}

Learners look for, identify, manipulate, organise, classify and evaluate information with the main aim of solving problems (Brown, 2006). M-learning uses this paradigm to provide lots of information for the learner to navigate; this is done through the social networks, podcasting and emails.

\subsection{Lifelong learning}

Learning occurs all the time and it is influenced by our environment and the situations in which we are (Sharples, 2000). Lifelong learning, which is personalised, situated, ubiquitous, collaborative and learner-centered, is compatible to M-learning which is personal, user-centered, networked, mobile and ubiquitous (Parajuli, 2016). Blogs, Wikipedia, mobile forums and podcasting are means through M-learning allows lifelong learning.

\section{Outcomes and Impact of M-Learning}

M-learning via SMS is the cheapest and easiest technology for the dissemination of information and knowledge to learners. SMS learning uses simple language that is very easy for understanding and it provides learners with relevant notes that can be easily remembered (Ziden, et al., 2017). Besides, it allows them to continue to study anywhere and at any time without the need to be connected to internet. The tutors can send brief learning materials and reminders to learners via SMS (Lai et al., 2013).

In addition, there are many forms of mobile phone quiz- or game- based systems. Quizzing can be combined to be used both as an assessment tool and a teaching technique (Urtel et al., 2006). After traditional face-to-face tutorials, learners may participate actively in out-of-the-class online quizzing, either to learn or to test their own learning themselves, or for the teacher to test knowledge applications by the former. With the use of quiz apps such as Quizlet LLC, Human Anatomy Atlas, etc, multiple choice questions are implemented in M-learning whereby learners answer each question by simply typing the letter or number and replying to the SMS they received with the MCQs (Brown \& Mbati, 2015). Quiz apps allow learners to have instant access to specialised information more efficiently and to be continuously engaged with the learning material, to experience less test anxiety and to increase their academic performance (Roediger \& Karpicke, 2006). Also, during class lectures, the use of clickers allows learners to answer questions anonymously and synchronously through a live polling system. As a matter of fact, the learning experience is more interactive (Foti \& Mendez, 2014). Serious games use pedagogy to input instruction into the game play experience (Tsekleves et al., 2014). They facilitate problem based learning and increase learners' motivation to learn more (Burguillo, 2010). In fact, games and quizzes are used for revision (Wishart \& Green, 2010).

Social media and other related applications such as YouTube allow learners to do instant personal publishing and sharing of texts, videos, audios and images (Brown \& Mbati, 2015). Besides, with M-learning, assignment due dates, teaching of concepts and clarification and reinforcement of lecture topics are possible through Facebook (Foti \& Mendez, 2014).

Audio-recording and playback functionalities on mobile devices allow learners to read and learn a word or a sentence aloud by recording it, replay it to listen to the pronunciation, and compare it to the correct one provided by the language learning programme or tutor (Brown \& Mbati, 2015). This production allows for active language learning with audio feedback and reflective learning (Ng'ambi, 2013). 


\section{Issues in Adopting M-Learning}

In adopting M-learning as an innovation to enhance teaching and learning, there are many issues that are of concern to its advocates. First, there are technical issues: learners spend more time searching for information than they need for reading because of the small screen size of mobile devices; mobile devices cannot support many files or diverse formats; they have limited memory capacity and there is the risk of obsolescence which may be an obstacle for continuous use of effective M-learning (a cognitive and ergonomic issue as well) by the tutors as well as the learners who would need months to learn to use the new apps (Maniar et al, 2008; Crescente \& Lee, 2011; Bidin \& Ziden, 2013).

Second, there are the usability issues. There is no universal platform for users as they do not have the same software apps and there are multiple operation systems; cooperative learning is hardly practicable since learners would take too much time to be familiar with the team members, tasks and procedures for collaboration; it is also difficult for users to get support for the appropriate use of the diverse functionality and resources and to have the digital assistance in case of technological problems (Mehdipour \& Zerehkafi, 2013; Brown \& Mbati, 2015; Sung et al., 2016).

There are also concerns about content security and copyright from the providers of knowledge (the tutors or the institution) and the creators of knowledge (learners). So, ownership of knowledge is the issue as M-learning may additionally conflict with the formal education, instead of complementing it (Parajuli, 2016). Images and content are provided, captured, re-used and created in various locations with great ease, and therefore this gives rise to the issue of privacy and data security or protection (Wishart \& Green, 2010). The risks of identity theft, stalking and cyber bullying are prevalent; users are advised about such risks but they are never protected (Bidin \& Ziden, 2013).

\section{Next Steps in M-Learning Adoption}

M-learning is an innovation and like any other innovation, there is likely to be many changes depending on the trends in education and technology. The next step is micro-feedback, whereby both learners and lecturers give and receive feedback on their learning and their teaching respectively during the instruction, and therefore there is likely to be increasing personification of feedback (Wishart \& Green, 2010). Another step would be adopting inclusive education in Mlearning. There would be the development of policies to promote accessibility for learners with disabilities (Mehdipour \& Zerehkafi, 2013). Moreover, it would lead to the implementation of the teaching digital literacy skills and visual media skills in early years of schooling and in the teacher professional development training (Brown \& Mbati, 2015). Another step is edugaming, after the success of serious games in M-learning. Finally, on account of the availability of numerous open source and free augmented reality software and applications, it is evident that there is likely to be greater use of simulations and augmented reality in M-learning (Brown \& Mbati, 2015).

\section{Conclusions}

M-learning is an innovative tool that is theoretically well grounded and that has proved to be successful in the developed countries which have the conducive teaching and learning formal and informal environment. This paper has made it evident that m-learning is a step further in the use of e-learning to support learners. It can be used to present learning content as well as to facilitate the learning process. However, its implementation requires that the education authorities or the knowledge providers to take into consideration the potential issues that may hinder the benefits of adopting it in designing learning activities. Moreover, the adoption of m-learning in developing countries like Nigeria and Mauritius, where learners may lack electracy skills and there is a lack of connectivity to internet in some regions, m-learning may not be a useful innovative tool in higher education institutions. 


\section{References}

Al Hassan, E. I. (2015). Mobile learning new technique to contribute the development of distance learning courses, as views from specialists of information and instructional technology in Sudanese universities. Journal of Education and Human Development, 4(1): 269-276.

Al-Awan, A., Al-Madadha, A. \& Zvirzdinaite, Z. (2018). Modelling students' readiness to adopt mobile learning in higher education: An empirical study. International Review of Research in Open and Distributed Learning, 19 (1): 221-241.

Alrasheedi, M., Capretz, L. \& Raza, A. (2015). Instructor perspectives of mobile learning platform: an empirical study. International Journal of Computer Science \& Information Technology, 7(3): 27-40.

Ashton, J. \& Newman, L. (2006). An unfinished symphony: $21^{\text {st }}$ century teacher education using knowledge creating heutagogies. British Journal of Educational Technology, 37(6): 825-840.

Batista, S. \& Barcelos, G. (2014). Considerations on the use of mobile phones in educational context. International Journal on Trends in Education and Their Implications, 5(1): 1-10.

Bidin, S. \& Ziden, A. A. (2013). Adoption and application of mobile learning in the education industry. Procedia Social and Behavioural Sciences, 90: 720-729.

Brown, J. S., Collins, A. \& Duguid, P. (1989). Situated cognition and the culture of learning. Educational Researcher, (18): 32-42.

Brown, T. \& Mbati, L. (2015). Mobile learning: Moving past the myths and embracing the opportunities. International Review of Research in Open and Distributed Learning, 16(2): 115-135.

Brown, T. H. (2006). Beyond constructivism: Navigationism in the knowledge era. On the Horizon, 14(3): 108120.

Bruner, J. (1966). Towards a theory of instruction. Cambridge, MA: Harvard university Press.

Burguillo. J. C. (2010). Using game theory and competition-based learning to stimulate student motivation and performance. Computers in Education, 55(2): 566-575.

Cormier, D. (2011). Rhimazotic learning: Why we teach? Available at http://davecormier.com/edblog/2011/11/05/rhizomatic-learning-why-learn/

Crescente, M. \& Lee, D. (2011). Critical issues of M-learning: Design models, adoption processes and future trends. Journal of the Chinese Institute of Industrial Engineers, vol. 28(2): 111-123.

Elmorshidy, A. (2012). Mobile learning - A new success model. The Journal of Global Business Management', 8(2): 18-27.

Foti, M. \& Mendez, J. (2014). Mobile learning: how students use mobile devices to support learning. Journal of Literacy and Technology, 15(3): 58-78.

Goggin, G. (2006). Cell phone culture: Mobile technology in everyday life. New York: Routledge.

Good, T. L. \& Brophy, J. E. (1990). Educational Psychology: A realistic approach, (4 ${ }^{\text {th }}$ ed.), White Plains, NY: Longman.

GSMA. (2013). Red Unx: From a MOOC platform to a mobile learning community for entrepreneurship in Latin America, London: GSMA, http://unesdoc.unesco.org/images/0023/002324/232450e.pdf

Huizenga, J., Admiraal, W., Akkerman, S. \& Dam, G. (2009). Mobile game-based learning in secondary education: engagement, motivation and learning in the mobile city game. Journal of computer Assisted Learning, 25(4): 332-344.

Keskin, N. \& Metcalf, D. (2011). The current perspectives, theories and practices of mobile learning. The Turkish Online Journal of Educational Technology, 10(2): 202-208.

Kimbell, R. A., Wheeler, A., Miller, S. \& Pollitt, A. (2007). E-scape portfolio assessment (e-solutions for creative assessment in portfolio environments). TERU Goldsmiths University of London ISBN 978-1-904158-79-0

Kramer, B. J. (2005). Mobile Learning: the next generation of learning Fern Universitat's contributions to the $2^{\text {nd }}$ year of the Leonardo Project mlearn2. Available at https://www.researchgate.net/publication/228377885_Mobile_Learning_The_Next_Generation_of_Learning

Kukulska-Hulme, A. (2009). Will mobile learning change language learning? $\operatorname{Re} C a l l, \overline{2} 1(2): 157-165$.

Lai, C. H., Yang, S. P., Yen, A. C. \& Chou, C. G. (2013). SMS and emails as class reminders to assist subject learning. Available at http://journals.sfu.ca/onlinejour/index.php/i-jim/article/viewFile/6332/4253

Maniar, N., Bennett, E., Hand, S. \& Allan, G. (2008). The effects of mobile phone screen size on video based learning. Journal of Software, 3(4): 51-61.

Martin, F. \& Ertzberger, J. (2013). Here and now mobile learning: An experimental study on the use of mobile technology. Computers and Education, 68: 76-85.

Mehdipour, H. \& Zerehkafi, H. (2013). Mobile learning for education: Benefits and challenges. International Journal of Computational Engineering Research, 3(6): 93-101.

Miller, W. (2012). iTeaching and learning: College instruction incorporating mobile tablets. Library Technology Reports, vol. 9. Retrieved from https://journals.ala.org/index.php//tr/article/view/4282/4908 
Ng'ambi, D. (2013). Effective and ineffective uses of emerging technologies: Towards a transformative pedagogical model. British Journal of Educational Technology, 44(2): 652-661.

Parajuli, K. P. (2016). Mobile learning practice in higher education in Nepal. Open Praxis, 8(1): 41-54.

Parsons, D. (2014). The future of mobile learning and implications for education and training. In Ally, M. \& Tsinakos, A., Editors, Perspectives on Open and Distance Learning: Increasing access through $M-$ learning. Commonwealth of Learning and Athabasca University, Vancouver: Canada.

Pedro, L., Barbosa, C. \& Santos, C. (2018). A critical review of mobile learning integration in formal educational contexts. International Journal of Educational Technology in Higher Education, 15(10): 1-15, https://link.springer.com/article/10.1186/s41239-018-0091-4

Quinn, C. (2000). M-learning: Mobile, wireless, in your pocket learning. Available at https://www.linezine.com/2.1/features/cqmmwiyp.htm

Rikala, J. (2016). Designing a mobile learning framework for aa aformaal educationl context. Jivskyla Studies in computing, University of Jivaskyla: Finland. Available at http://journals.sfu.ca/onlinejour/index.php/ijim/article/viewFile/6332/4253

Roediger, H. L. \& Karpicke, J. D. (2006). The power of testing memory: Basic research and implications for educational practice. Perspectives on Psychological Science, 1: 181-210.

Sfard, A. (1998). On two metaphors for learning and the dangers of choosing just one. Educational Researcher, 27(2): 4-13.

Sharples, M. (2000). The design of personal mobile technologies for lifelong learning. Computers \& Education, 34(3-4): 177-193.

Sharples, M., Taylor, J. \& Vavonla, G. (2007). A theory of learning for the mobile age, R, Andrews and C, Haythornthwaite, The Sage Handbook of Elementary Research, Sage Publications, pp. $221-217$. Available at https://pdfs.semanticscholar.org/59c7/114da68dfccb7431fbe1e7fff6b727c8234c.pdf

Smith, P. L. \& Ragan, T. J. (2005). Instructional design ( $3^{\text {rd }}$ ed, ), New York: Merill.

Sung, Y., Chang, K. \& Lui, T. (2016). The effects of integrating mobile devices with teaching and learning on students' learning performance: A meta-analysis and research synthesis. Computers and Education, 94: 252-275.

Thomas, T., Singh, L. \& Gaffar, K. (2013). The utility of the UTAUT model in explaining mobile learning adoption in higher education in Guyana. International Journal of Educational and Development using Information and Communication Technology, 9(3): 71-85.

Traxler, J. (2007). Defining, discussing and evaluation M-learning: the moving finger writes and having writ... International Review of Research in Open and Distance Learning, 8(2). Available at http://www.irrodl.org/index.php/irrodl/article/view/346/875

Tsekleves, E., Cosmas, J. Aggoun, A. (2014). Benefits, barriers and guideline recommendations for the implementation of serious games in education for stakeholders and policymakers. British Journal of Educational Technology, doi:10.1111/bjet.12223

Tsipursky, G. (2013). Class-sourcing as teaching strategy. Inside Higher Ed, https://www.insidehighered.com/advice/2013/10/18/class-sourcing-teaching-strategy-essay

Unwin, T. (2015). Evolution and prospects for the use of mobile technologies to improve education access and learning outcomes, UNESCO. Available at http://unesdoc.unesco.org/images/t0023/002324/232450e.pdf

Urtel, M. G., Bahamonde, E, R., Mikesky, A. E., Udry, E. M, \& Vessely ,J. S. (2006). Online quizzing and its effect on student engagement and student performance. Journal of Scholarship of Teaching and Learning, 6(2): 84-92. https://files.eric.ed.gov/fulltext/EJ854928.pdf

Wang, S., Wu, C. \& Wang, Y. (2009). Investigating the determinants and age and gender differences in the acceptance of mobile learning. British Journal of Educational Technology, 8(10): 969-979.

Wishart, J. \& Green, D. (2010). Identifying emerging issues in mobile learning in higher and further education: A report to JISC. Available at http://www.bristol.ac.uk/medialibrary/sites/education/migrated/documents/emergereport.pdf

Ziden, A. A., Rosle, M., Gunasegaran, T. \& Azizan, S. N. (2017). Perceptions and experiences in Mobile learning via SMS. International Journal of Information Management, 11(1): 116-132. 